\title{
Purification of Full-Length $\beta$-Secretase Involved in Alzheimer's Disease, and Proteomic Identification of Binding Partners
}

\author{
Lucy Ly ${ }^{1,2}$, Richard Parsons ${ }^{3}$, Brian Austen ${ }^{2}$ \\ ${ }^{1}$ Lipid Mediator Unit, William Harvey Research Institute, Barts and the London Medical Schools, London, UK; \\ ${ }^{2}$ Department of Biomedical Science, St George's University of London, London, UK; ${ }^{3}$ Institute of Pharmaceutical \\ Science, King's College London, London, UK
}

Correspondence to: Brian Austen, sghk200@sgul.ac.uk

Keywords: Alzheimer's Disease, $\beta$-Amyloid, $\beta$-Secretase, Purification, Protein Complex, Endoplasmic Reticulum, Proteomics

Received: December 16, $2019 \quad$ Accepted: January 27, $2019 \quad$ Published: January 30, 2019

Copyright $\odot 2020$ by author(s) and Scientific Research Publishing Inc.

This work is licensed under the Creative Commons Attribution International License (CC BY 4.0).

http://creativecommons.org/licenses/by/4.0/

\section{(c) $\underset{\mathrm{gy}}{\mathrm{gy}}$ Open Access}

\section{ABSTRACT}

$\beta$-Secretase (BACE1 or $\beta$-site APP cleaving enzyme) is an acid protease that releases the neurotoxic 40 - 42 residue peptides ( $\beta$-amyloid or $A-\beta$ ) from its glycoprotein precursor, (APP or amyloid precursor protein) which when released in brain is thought to give rise to cognitive decline in patients with Alzheimer's Disease. Most structural studies on $\beta$-secretase have previously been performed with recombinant forms of the protease, in which the transmembrane coding region has been deleted. However, interactions with proteins of the same species are best studied using the full-length $\beta$-secretase as interactions are likely to be influenced by the hydrophobic nature and localization of its transmembrane regions. Here we develop a multi-step purification procedure that isolates a complex containing BACE1 from recombinant human cells using mild detergents in a procedure that retains other proteins within the complex and remains active in its $\beta$-site APP cleaving activity. Some of these proteins, eg reticulon 4 , are identified by proteomics, and are known by previous studies performed by others to regulate the activity of BACE1 against APP. These interactions may aid the development of small proteins and peptides that could inhibit the release of aggregated forms of $\beta$-amyloid, and thus be useful therapeutically.

\section{INTRODUCTION}

Alzheimer's disease (AD) is a common age-related dementia, which is characterized pathologically by the appearance in the brain of two characteristic lesions which define AD: 1) amyloid plaques, which are 
extracellular deposits primarily composed of aggregated forms of the 4-kDa, 40- to 42-amino-acid $\beta$-amyloid (A- $\beta$ ) peptide [1] a product of proteolysis of the amyloid precursor protein (APP); and 2) neurofibrillary tangles, intracellular aggregates of the microtubule-associated protein tau [2]. The relationships between amyloid plaques, neurofibrillary tangles, and the pathophysiological mechanisms underlying $\mathrm{AD}$ have been controversial. However, evidence strongly suggests that $\mathrm{A}-\beta$ is critically involved at early stages in the pathogenesis of $\mathrm{AD}$ brain senile plaques. $\mathrm{A}-\beta$ is the collective term describing 39 - 43 residue peptides, covering the same region of APP, which are released by different proteolytic processing. The amyloidogenic pathway requires that APP is sequentially cleaved by $\beta$ and $\gamma$ secretases (Figure 1) $\beta$-Secretase (BACE1 also termed Memapsin-2 and Asp-2) cleaves APP close to the membrane to produce $\beta$ APPs (secreted), and the $12-\mathrm{kDa}, \mathrm{C} 100$ transmembrane stub, subsequently cleaved by $\gamma$-secretase to produce the A- $\beta$ peptides and cytoplasmic fragments with very short half life. $\alpha$-Secretase cleaves APP within the A- $\beta$ sequence thus preventing its formation, producing the $\mathrm{N}$-terminal $\alpha$ APPs domain and the $10-\mathrm{kDa}$ membrane-localised C-terminal stub, C83 (Figure 1). As aggregated A- $\beta$ is thought to promote neuronal death $[3,4]$, the secretases represent potential drug targets for the treatment and/or prevention of $\mathrm{AD}$.

The initially translated protein from the BACE1 gene, which is on chromosome 11q23 (near an area with LOD scores associated with early-onset Alzheimer's) [9] is highly modified as it moves through the cell. As well as signal peptide cleavage, disulphide formation and pro-sequence removal, extensive glycosylation, lipidation and phosphorylation occur. Moreover, the BACE1 protein forms dimers, and engages in important interactions with other proteins in ways which alter its mode of action, and its interaction with its substrate of the amyloid precursor protein (APP), and thus has implications for the release of A- $\beta$ in the brain. The BACE1 gene codes for a signal peptide, a pro-peptide

(22-TQHGIRLPLRSGLGGAPLGLRLPR-46), and two catalytic domains homologous to those in other aspartyl proteinases, the transmembrane segment and a cytoplasmic C-terminal tail (Figure 2). Several cysteine residues are present, six of which are in the luminal domain which may form intramolecular disulphide bridges contributing to the folding of the active site [13]. BACE1 is extensively glycosylated [14] and phosphorylated [15], and contains S-palmitoyl groups which may aid membrane anchorage [16]. The post-translational modifications of BACE1 are summarized in Figure 2 [12]. In the mature protein, the lumenal domain extends from residues 46 - 460 and comprises the active site where BACE1 cleaves APP [7, 16]. BACE1 has two active site motifs, DTGS from residues 93 - 96 and DSGT from residues 289 - 292 [17], mutations in which render BACE1 inactive [13]. BACE1 has several N-glycosylation and phosphorylation sites [15] and palmitate residues are known to modify C-terminal residues in the cytoplasmic domain [12, 17]. The signal for BACE1 intracellular transport, also known as the acid cluster dileucine (ACDL) sequence, is located in the C-terminal region (Figure 1). The $\mathrm{N}$-terminal 21 residues of the initially translated form of BACE1 act as a typical signal sequence to attach polysomes carrying its nascent chain to a pore complex in the membranes of the rough endoplasmic reticulum. Translocation occurs until the membrane insertion sequence (residues 458 - 478) inserts into the membrane. N-glycosylation and disulphide formation occur at these early stages. The signal is cleaved off during or shortly after translocation at Thr22 to release the N-terminus of the 23/24-residue Pro sequence. Activation of acidic proteases by removal of a pro-sequence occurs either by autocatalysis, as in the case of pepsinogen, and other aspartic proteases, or the action of additional proteases, such as pro-convertase or furin. We showed that purified recombinant BACE1 cleaves its own pro-peptide at $\mathrm{pH} 5$ but not at $\mathrm{pH} 8.5$, by the release of two peptides from the pro-domain QHGIRLPLR and SGLGGAPLGLRLPR [17]. The furin inhibitor EDTA had no effect on the release of these peptides, whereas the BACE1 inhibitor

(Lys-Thr-Glu-Glu-Ile-Ser-Glu-Val-Asn-Sta-Val-Ala-Phe-OH from Bachem) reduced the release of the pro peptides, showing that cleavage was by autocatalysis, and not by the activity of furin impurity. The low $\mathrm{pH}$ optimum of the Pro-peptide release indicates that Pro cleavage may be a late event in the targeting pathway, at acidic endosomes. The results also showed that the possibility of treating Alzheimer's with inhibitors of furin activation is not viable. 


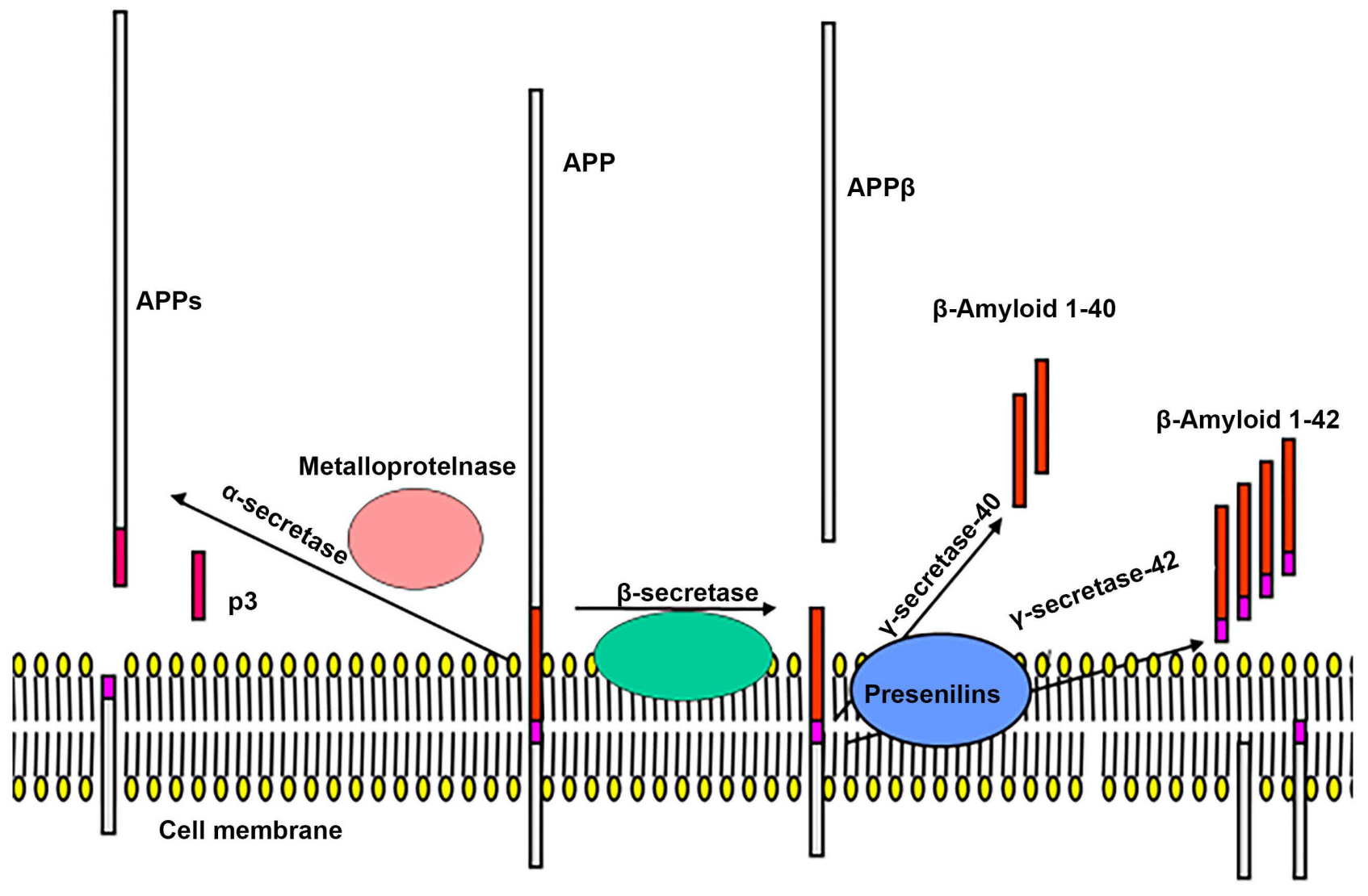

C-terminal fragments

Figure 1. A schematic showing proteolysis of APP. APP, a transmembrane glycoprotein, may be cleaved by $\beta$-secretase, to release a secreted portion of the glycoprotein, and a membrane-embedded stub, which rapidly degrades. Alternatively, APP is cleaved by $\beta$-secretase on the luminal side of the membrane, and by $\beta$-secretase in the membrane to release $\beta$-amyloid-40 or $\beta$-amyloid-42. Presenilin-1 was suggested to be the ideal candidate for $\gamma$-secretase, whereas $\alpha$-secretase has been characterised as ADAM10 disintegrin and metalloprotease [5]. Several groups used expression cloning, genomic search, or purification and proteomic analysis [6-8] to clone and identify $\beta$-secretase as an aspartic endopeptidase (EC 3.4.23.46) named BACE1 ( $\beta$-site APPcleavage enzyme 1), ASP-2 (aspartic protease 2), or memapsin 2. An additional candidate, BACE2, ASP-1, or memapsin-1, has also been cloned [9-11] but BACE2, unlike BACE1, is not concentrated in brain, and does not release the full $A-\beta$ sequence from APP.

\subsection{Glycosylation}

The BACE1 sequence contains four potential N-glycosylation sites (Figure 2). Tunicamycin reduces the activity of BACE1 to about $40 \%$ against APP, indicating the oligosaccharide moieties are important for activity. Three double mutants in which two of the acceptor Asn residues were replaced by non-acceptor residues, were only partially active $(30 \%-40 \%)$. All four Asn acceptor residues have heterogeneous oligosaccharides attached [14]. The oligosaccharides released from the mature protein are of bi-, tri-and tetra-antennary types, when expressed from mammalian cells in culture. Inhibition of $\beta$-secretase proteolytic activity was due either to induction of incorrect folding of the protein or by steric inhibition of APP binding by the changes in the oligosaccharides. Maturation of one of the complex oligosaccharides was found to be markedly affected by treatment of expressing cells with the cholesterol-biosynthesis inhibitor, 

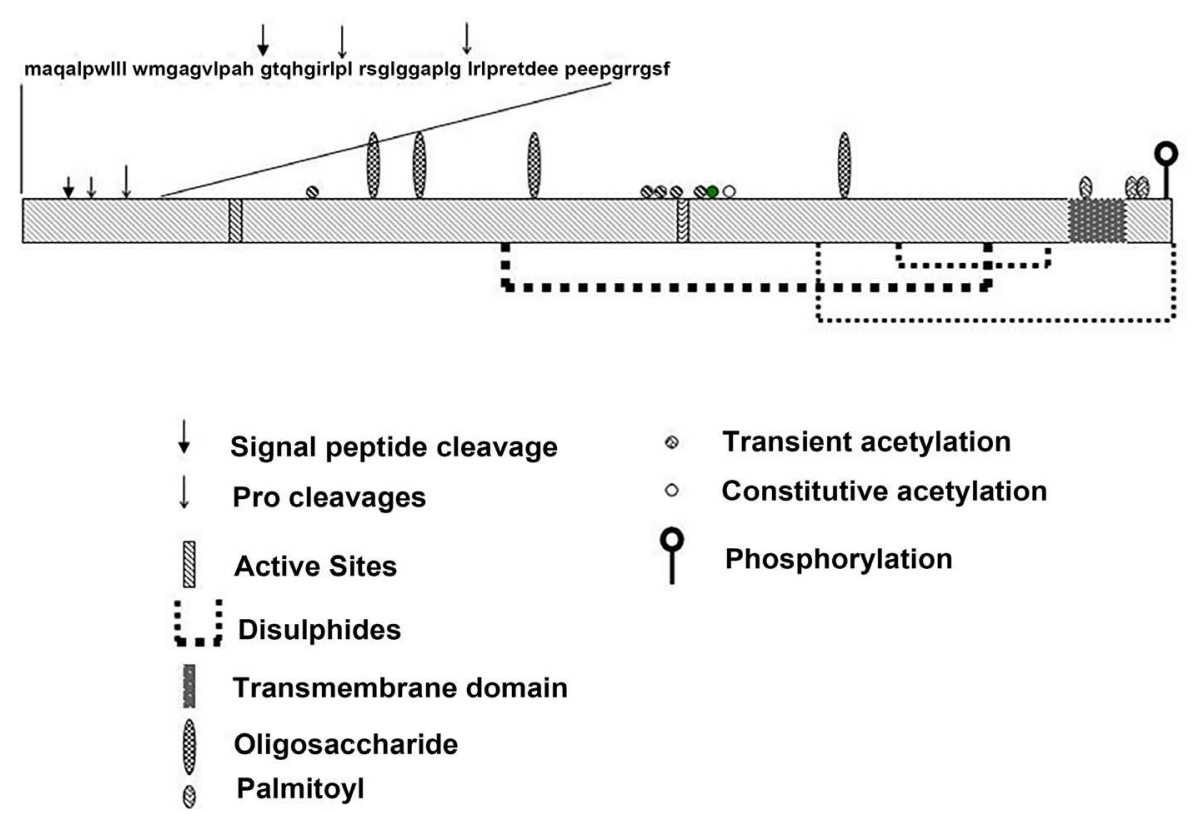

Figure 2. Modifications of BACE1. From Parsons \& Austen (2008) [12].

lovastatin, which has been shown to lower risk of Alzheimer's disease in the human population [18]. At least some of the terminal saccharides are sulphated.

\subsection{Aims of the Present Study}

A procedure was developed to purify a complex of proteins that included full-length BACE1. It is important to know what protein-protein interactions in the membranes of cells in brain regulate the release of $\beta$-amyloid; overexpression or chemical mimicry of inhibitory proteins and their binding sites could lead to the development of drugs that depress the release of $\beta$-amyloid, and thus have therapeutic properties. Many of those interactions depend on the membrane insertion and cytoplasmic domains, and thus can only be explored in complexes involving the full-length protein in human cells.

\section{PURIFICATION OF THE BACE1 COMPLEX}

\subsection{Materials and Methods}

pcDNA3.1MycHis Asp2 engineered with a polyhistidine coding tag and a c-myc epitope downstream of the full coding sequence of the aspartic protease Asp 2 was kindly provided by GSK Laboratories (Harlow, UK). Methods of cell culture and protein analysis were as described by [12]. BACE was detected using an anti-BACE affinity-purified rabbit polyclonal antibody, raised against residues 482 - 501

(CLRQQHDDFADDISLLK) of BACE1 [developed in our laboratory, and purified on a form of the peptide which was immobilized at its $\mathrm{N}$-terminus [12]. $\beta$-secretase activity kit was obtained from R\&D systems (Abingdon, UK) (cat FP002).

\subsection{Purification of Full-Length BACE}

There is a great interest in studying potential protein-interactions that modulate BACE1 activity as they may provide therapeutic targets in the management and prevention of AD. However, as with many integral membrane proteins, purification of BACE1 is plagued with the problem of protein insolubility. BACE1 is expressed in organisms at low levels, and is therefore difficult to purify and requires a combination of detergents that retain solubility, whilst retaining function and activity in aqueous conditions. Unlike previously reported purification systems for $\beta$-secretase [19], techniques to isolate and purify potential 
binding partners of BACE1 are determined by the need to create conditions that do not disrupt a BACE1 complex with other protein binding partners. BACE1 is active in acidic conditions with a $\mathrm{pH}$ optimum of 6.0, but proteins that interact with BACE1 may require different optimum conditions for their activity, complicating their isolation and purification. Although several reports have described the purification of BACE1 truncated on the N-terminal side of its membrane-binding section from Drosophila melanogaster S2 cells and Escherichia coli [20-23], these organisms may not possess homologous interacting proteins. Therefore, isolating BACE1 from human cell lines and identifying its active binding partners will ultimately provide a greater insight into how these protein interactions affect BACE1 and their role in the generation of $\beta$-amyloid.

$50 \times 10^{6}$ Asp2-transfected cells overexpressing full-length BACE1 protein were suspended in growth media, centrifuged then successively washed $\times 3$ with Dulbecco's modified saline $(10 \mathrm{ml})$ at $4^{\circ} \mathrm{C}$, centrifuging at $1400 \times \mathrm{g}$ for $10 \mathrm{~min}$. Pellets were resuspended in $50 \mathrm{mM}$ MES $(10 \mathrm{ml}), 150 \mathrm{mM} \mathrm{NaCl}$ and $5 \mathrm{mM}$ $\mathrm{CaCl}_{2}$ ( $\mathrm{pH}$ 6.0) by homogenization in a Potter-Elvejehm glass homogenizer, and sonicated at $80 \mathrm{mHx}$ twice for 20 secs in ice. Nuclei and unbroken cells were removed by centrifugation at $9700 \times \mathrm{g}$ for $10 \mathrm{~min}$, and intracellular membranes isolated as a pellet by centrifugation at $100,000 \times \mathrm{g}_{\mathrm{av}}$ for $1 \mathrm{hr}$ at $4^{\circ} \mathrm{C}$. The pellet was then washed with high $\mathrm{pH}$ sodium bicarbonate wash $\left(0.1 \mathrm{M} \mathrm{NaHCO}_{3}, \mathrm{pH} 11.3\right)\left(5 \mathrm{ml}\right.$ at $\left.4^{\circ} \mathrm{C}\right)$ by pipetting up and down at $4^{\circ} \mathrm{C} 30$ times to remove peripheral membrane proteins and cytosolic proteins, whilst maintaining integral membrane proteins in pelleted form. The proteins in the pellet were then solubilized in a neutral buffer ( $\mathrm{pH} 7.0)$ containing $1 \%$

C3-[(3-Cholamidopropyl)dimethylammonio]-1-propanesulfonate (CHAPS) and protease inhibitors in $50 \mathrm{mM}$ HEPES, $150 \mathrm{mM} \mathrm{NaCl}, 5 \mathrm{mM} \mathrm{MgCl}_{2}, 5 \mathrm{mM} \mathrm{CaCl}_{2}$. A further purification step was performed to separate and isolate the BACE1 complex according to its size and shape in a glycerol velocity gradient in a centrifuge at $200,000 \times \mathrm{g}_{\mathrm{av}}$ for 15 hours. $1 \mathrm{~mL}$ of solubilised BACE1 preparation was loaded onto a column of $18 \%-28 \%$ gradient glycerol solution prepared in $50 \mathrm{mM}$ HEPES (pH7.0) and supplemented with $0.2 \%$ digitonin to maintain solubility. Western blot analysis was used to monitor the purification of BACE (Figure 3).

$1 \mathrm{~mL}$ solubilized bicarbonate extract was loaded onto a $18 \%-28 \%$ glycerol-HEPES gradient supplemented with $1 \%$ digitonin and centrifuged at 200,000 $\mathrm{g}_{\mathrm{av}}$ for $16 \mathrm{~h}$. Each $1 \mathrm{~mL}$ layer of glycerol-HEPES solution was collected and analysed by western analysis (100 $\mu \mathrm{g}$ protein loaded onto gel) and revealed the presence of BACE1 in all membrane preps (Lane 1 to Lane 3) and glycerol velocity gradients fractions (lane 4 to lane 14). Heaviest staining for BACE1 was detected in the sodium bicarbonate wash supernatant (Lane 2) and solubilised BACE1 prep (Lane 3). 19\% GVG fraction (Lane 5) showed very little BACE1 and 20\% GVG showed no BACE1. 24\% and 26\% GVG fractions revealed dimeric BACE1 with an approx. MW of $144 \mathrm{kDa}$ (Lane 10 \& Lane 12).

Results showed that whereas a small amount of BACE was solubilized by bicarbonate, most BACE was purified into a membrane fraction that could be solubilized by buffers containing CHAPS or digitonin detergents. Gradient density centrifugation of the membrane fraction indetergent concentrated monomeric and dimeric BACE into fractions containing 24\% - 26\% glycerol (Figure 3).

The membrane-associated BACE complex was further purified by IEC with DEAE Sephadex. $1.5 \mathrm{~mL}$ pooled $24 \%$ - $26 \%$ glycerol velocity gradient fractions of BACE1 complex was injected onto a gravity-assisted $5 \mathrm{~mL}$-packed DEAE Sephadex column (pre-equilibrated in $10 \mathrm{mM}$ HEPES, protease inhibitors and $0.2 \%$ digitonin) and incubated for 5 mins at $4{ }^{\circ} \mathrm{C}$ to allow proteins to bind to the charged resin. Bound proteins were steadily eluted from the column with a linear gradient of $50 \mathrm{ml} 10 \mathrm{mM}$ HEPES buffer containing protease inhibitors and $0.2 \%$ digitonin mixing with $50 \mathrm{ml}$ of the same buffer containing in addition $1 \mathrm{M} \mathrm{NaCl}$. Eluate was assayed by a fluorometric assay for $\beta$-secretase (Figure 4). Activity was most concentrated in Fraction 7, which was then analysed by proteomics.

Table 1 summarizes the measured activity of $\beta$-secretase/BACE1 following the multistep purification and the percentage of recovered proteins. It shows a large reduction in the percentage of recovered $\mathrm{BACE}$ activity and protein following high speed centrifugation (post-nuclear supernatant, detergent solubilisation of the BACE1 complex, density-centrifugation and anion-exchange chromatography with DEAE 


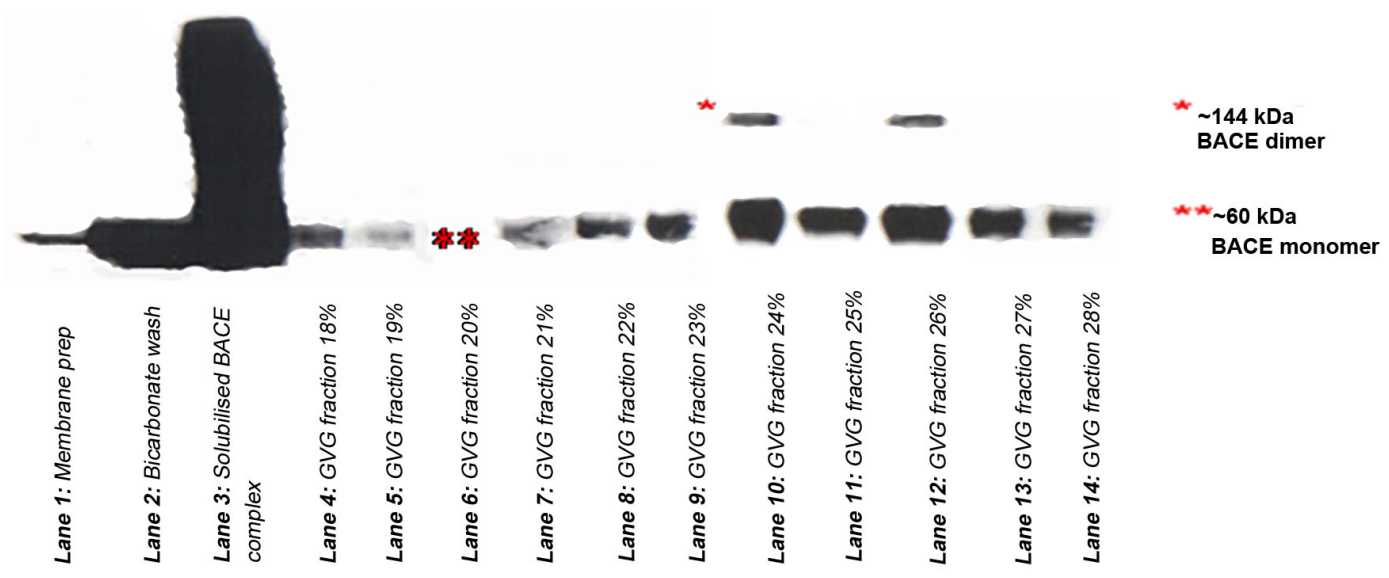

Figure 3. Density gradient separation of membranes containing BACE.

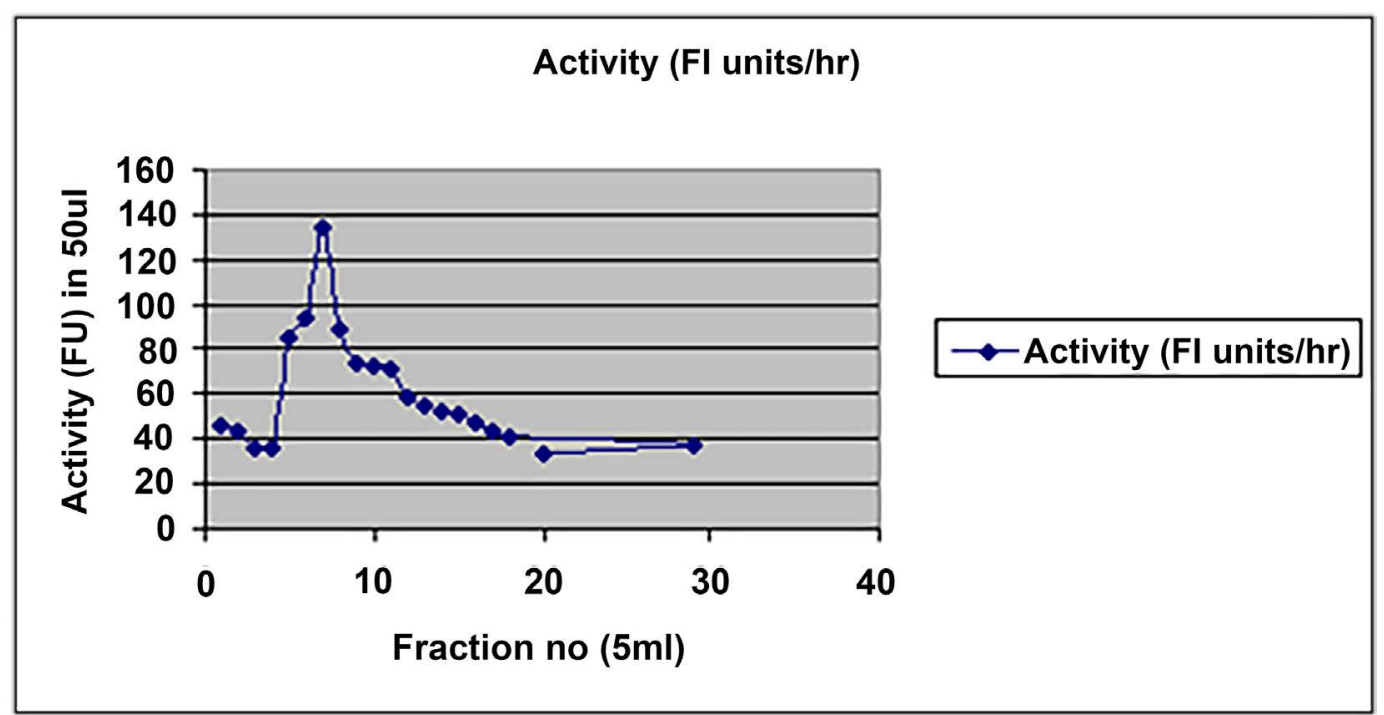

Figure 4. Purification of BACE1 complex by ion exchange chromatography (IEC).

Table 1. Recovery of $\beta$-secretase in a 5 -step purification procedure.

\begin{tabular}{|c|c|c|c|c|c|c|c|}
\hline Fraction & $\begin{array}{l}\text { Tot vol. } \\
(\mathrm{ml})\end{array}$ & $\begin{array}{l}\text { Protein } \\
\mathrm{ug} / \mu \mathrm{l}\end{array}$ & $\begin{array}{l}\text { Tot. protein } \\
\text { (ug) }\end{array}$ & Activity/50 ul & Spec.activity & Tot. activity & Recovery \% \\
\hline cell lysate & 5 & 5.75 & 28,760 & 73.26 & 12.7 & 366,300 & 100 \\
\hline Post-nuc SN & 5 & 1.25 & 6250 & 18.9 & 15.1 & 94,500 & 25.8 \\
\hline bicarb. pellet in det. & 5 & 5.29 & 26,450 & 33.74 & 6.4 & 31,900 & 8.7 \\
\hline Dens Grad Frs 24\% - 26\% & 2 & 3.2 & 6390 & 37.44 & 11.7 & 23,420 & 6.4 \\
\hline DEAE Fr7 & 5 & 1.05 & 5350 & 2.68 & 2.6 & 12,750 & 3.5 \\
\hline
\end{tabular}

sephadex were also observed, showing much of the secretase remained with the particulate material at this stage. The results showed considerable loss of activity during purification, especially in the IEC step, sugesting the procedure is far from optimum. The number of bands in an SDS-PAGE analysis of Fr7, however indicated only a few attached proteins in the complex (Figure 5), which were analysed by proteomics. 


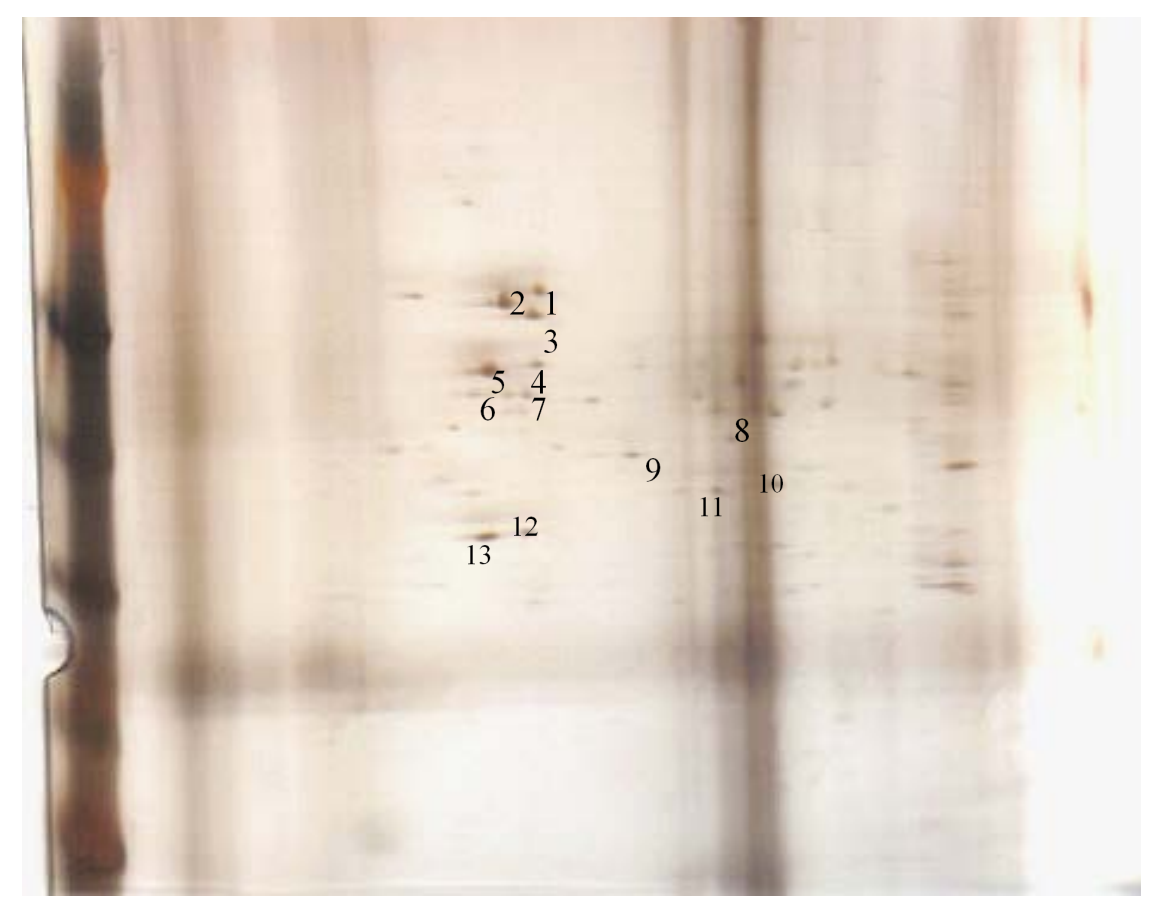

Figure 5. 2D-gel electrophoresis of fraction 7 of the BACE complex from DEAE-Sephadex chromatography run in digitonin, showing about 13 major proteins and a number of minor ones.

\section{IDENTIFICATION OF BINDING PARTNERS BY PROTEOMICS}

Gel bands were briefly dehydrated with $200 \mu \mathrm{L}$ ACN and the solution aspirated. Residual ACN was evaporated in a SpeedVac evaporator, at low temperature setting for 5 minutes. Proteins in gel slices were reduced in $100 \mu \mathrm{L} 10 \mathrm{mM}$ dithiothreitol (DTT) at room temperature for 30 minutes and then alkylated in $100 \mu \mathrm{L} 50 \mathrm{mM}$ iodoacetamide in the dark for 30 minutes at room temperature; the supernatant solution was aspirated from the gel piece, which were dehydrated twice with $200 \mu \mathrm{L}$ ACN and rehydrated with 100 $\mu \mathrm{L} 100 \mathrm{mM}$ ammonium bicarbonate, for 10 minutes and dried with a SpeedVac evaporator, for 5 minutes. Selected protein (gel bands) were excised and washed in $100 \mu \mathrm{L} 100 \mathrm{mM}$ ammonium bicarbonate and incubated with $30 \mu \mathrm{l}$ sequencing-grade trypsin on ice for $45 \mathrm{~min}$, then for $8 \mathrm{hr}$ at $37^{\circ} \mathrm{C}$.

17 bands were analysed, and tryptic fragments identified in the full Swissprot human data base using Mascot. Peptide scores represents the highestions score for each distinct peptide sequence and were estimated by comparing the search results against an estimated random match population [24] (Table 2).

As well as $\beta$-secretase itself, other proteins identified in the BACE1 complex by mass spectrometry (Table 2) were reticulon 4, endoplasmin and GRP-78, proteins from the endoplasmic reticulum thought to be involved in the maturation and processing of newly-synthesised proteins. Membrane bound reticulon (RTN) family proteins interact with BACE1 and negatively modulate BACE1 activity through preventing access of BACE1 to its cellular APP substrate. It has previously been shown by [25] that a C-terminal QID triplet conserved among mammalian RTN members is required for the binding of RTN to BACE1. Although reticulons can form homo- or heterodimers in cells, BACE1 mainly binds to the RTN monomer and disruption of the QID triplet does not interfere with the dimerization. Correspondingly, the C-terminal region of BACE1 is required for the binding of BACE1 to RTNs. Furthermore, it has been shown by others that the negative modulation of BACE1 by RTN3 relies on the binding of RTN3 to BACE1. The knowledge from this study may potentially guide discovery of small molecules, maybe peptides, that can mimic the effect of RTN3 on the inhibition of BACE1. An example of the MS1 and MS2 spectra from peptide with a high matching score [24] from reticulon 4 is shown (Figure 6). 
Table 2. Identification by mass. spec. of proteins isolated from 2D-separation of BACE1 complex.

\begin{tabular}{cccccc}
\hline Spot No. & Protein & Accession & Predicted MW & Actual MW & Peptide score \\
\hline 1 & Reticulon 4 & RTN4_HUMAN & 129.8 & 167.8 & 69 \\
2 & $\beta$-Secretase (dimer) & BACE1_HUMAN & 111.2 & 128.2 & 154 \\
3 & Endoplasmin & ENPL_HUMAN & 92.4 & 97.0 & 162 \\
4 & Glucose regulated protein & GRP78_HUMAN & 72.2 & 85.6 & 238 \\
5 & Heat shock cognate protein & HSP7C_HUMAN & 70.8 & 76.0 & 418 \\
6 & Heat shock protein & HSP71_HUMAN & 70.0 & 68.8 & 131 \\
7 & $\beta$-Secretase (monomer) & BACE1_HUMAN & 55.6 & 61.4 & 166 \\
8 & Heat shock protein (mito) & CH60_HUMAN & 61.0 & 57.6 & 104 \\
9 & ATPsynthase $\alpha$ mitochondrial & ATPA_HUMAN & 59.7 & 56.2 & 196 \\
10 & ATPsynthase. $\beta$ mitochondrial & ATPB_HUMAN & 56.5 & 53.6 & 138 \\
11 & $\alpha$-Enolase & ENOA_HUMAN & 47.1 & 47.4 & 152 \\
12 & Cytochrome b-c1 & QCR2_HUMAN & 48.4 & 45.0 & 93 \\
13 & $\beta$-Secretase 1 (monomer) & BACE1_HUMAN & 55.6 & 42.6 & 123 \\
14 & $\beta$-Secretase 1 (monomer) & BACE1_HUMAN & 55.6 & 39.0 & 68 \\
15 & Lactate dehydrogenase Bchain & LDHB-HUMAN & 36.6 & 36.8 & 178 \\
\hline
\end{tabular}
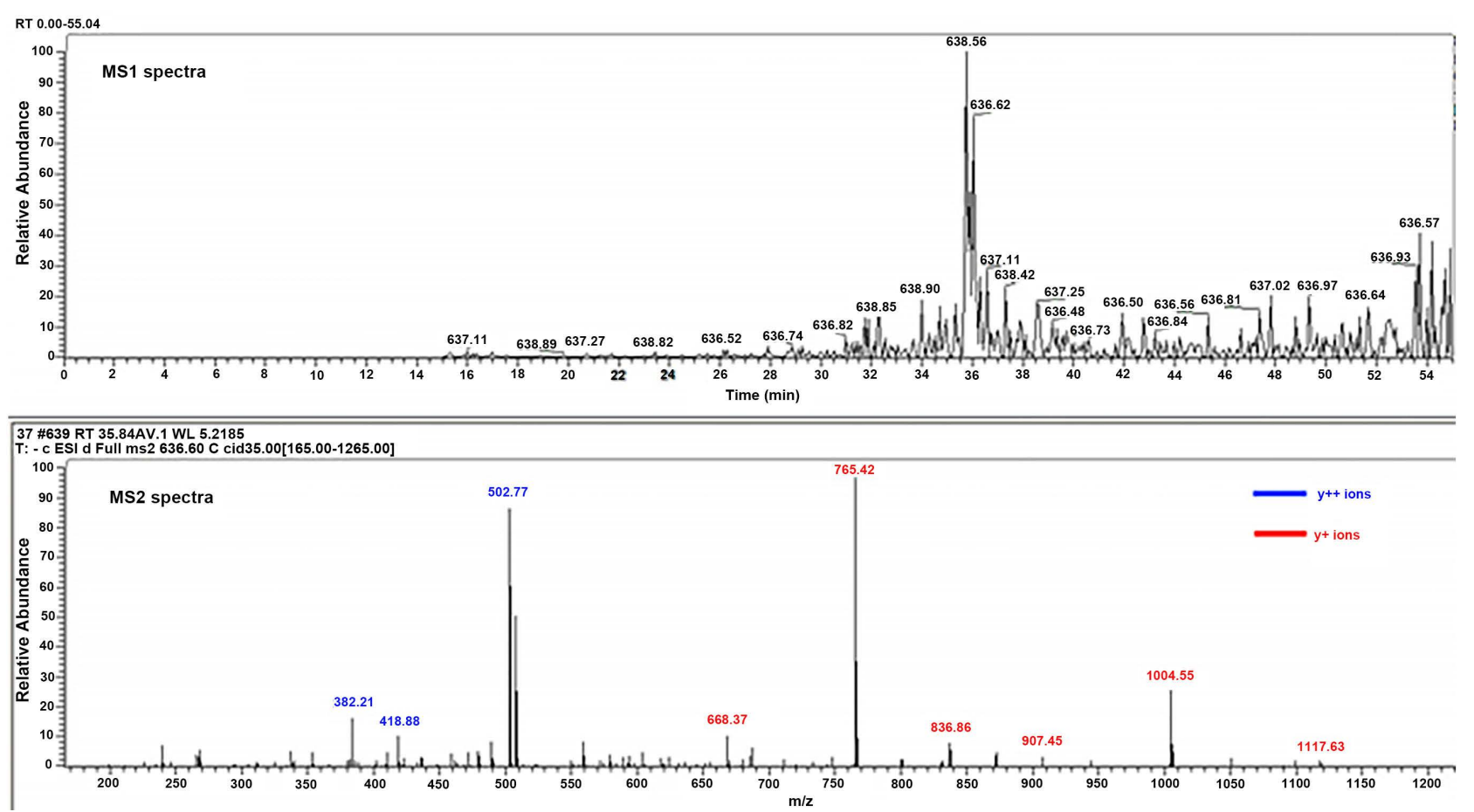

Figure 6. MS Spectral profile of peptide GPLPAAPPVAPER (protein ID 1-Reticulon 4).Liquid chromatography-tandem mass spectrometry (LC-MS/MS) was performed using an LCQ-DECA Thermofinnigan Surveyor high performance liquid chromatography (HPLC) mass spectrometer (Thermo Scientific). Firstly, $3 \mu \mathrm{L}$ of tryptic digests were separated by HPLC and eluted with a gradient of acetonitrile in $0.1 \%$ formic acid at $400 \mu \mathrm{l} / \mathrm{min}$ over $55 \mathrm{~min}$. The effluent was then injected (by electrospray) into an ion trap and ionized to generate the MS1 and MS2 spectras. MS2 was obtained from the doubly charged parent ion $\mathrm{m} / \mathrm{z}$ of 636.60 . 
The reticulons are known to stabilize the tubular structure of the endoplasmic reticulum, and also to regulate neurite growth. Reticulon 3 and -4 have been shown to inhibit $\beta$-secretase activity [25]. Overexpression of these reticulons (RTNs) resulted in a 30\% - 50\% reduction in the secretion of both Abeta40 and Abeta42 from HEK293 cells expressing the AD-associated Swedish mutant amyloid precursor protein (APP), but did not affect Abeta secretion from cells expressing the APP beta-C-terminal fragment (beta-CTF), indicating that these RTNs can inhibit BACE1 activity [26]. Reduction of the stability of reticulon 3 is known to increase $\beta$-amyloid formation in transgenic (APP (PS1)) models of Alzheimer's Disease. Thus understanding the interaction of $\beta$-secretase with reticulon 4 could lead to the development of small molecule or peptide inhibitors that would have therapeutic value in patients. Three regions, residues 59 172, $544-725$ and the loop 66 amino acids, between the two transmembrane domains, known as Nogo-66 (neurite Outgrowth Inhibitor or nogo -66) loop, appear to be responsible for the inhibitory effect on neurite outgrowth and the spreading of neurons. This Nogo-66 loop, mediates also the binding of RTN4 to its receptor. The TM1 and TM2 of RTN3 consist of 34 and 31 amino acid residues, respectively, longer than usual for transmembrane domains, which are typically 20 amino acid residues in length. The other mammalian RTN family proteins and their homologs in lower organisms similarly contain two long hydrophobic regions [27]. The precise membrane topology of RTN proteins has not been resolved, although possible topological models are predicted [28]. It has been found that RTN3 $\Delta$ TM1 and RTN3 $\Delta T M 2$ bind to BACE1 but lack the ability to inhibit $\mathrm{A} \beta$ generation. The two-hydrophobic domain tertiary structure of reticulon proteins is critical for modulation of $\beta$-secretase BACE1 [29]. The $\mathrm{N}$-terminal part, called Am-Nogo-B (1 - 200), is the functional domain for RTN4B-mediated signaling in endothelial and vascular smooth muscle cells.

\section{SUMMARY}

There is a great interest in studying potential protein-interactions that modulate BACE1 activity as they may aid structural design of therapeutic agents useful for the management and prevention of $A D$ [30]. However, as with many integral membrane proteins, purification of BACE1 is plagued with the problem of protein insolubility. BACE1 is expressed in organisms at low levels, and is therefore difficult to purify and requires a combination of detergents that retain solubility, whilst retaining function and activity in aqueous conditions. Unlike previously reported purification systems for $\gamma$-secretase [19], techniques to isolate and purify potential binding partners of BACE1 were determined by the need to create conditions that do not disrupt a BACE1 complex with other protein binding partners. BACE1 is active in acidic conditions with a $\mathrm{pH}$ optimum of 6.0, but proteins that interact with BACE1 may require different optimum conditions for their activity, complicating their isolation and purification. Although several reports have described the purification of BACE1 truncated on the N-terminal side of its membrane-binding section from Drosophila melanogaster S2 cells and Escherichia coli [20], these organisms may not possess homologous interacting proteins. Therefore, isolating BACE1 from human cell lines and identifying its active binding partners will ultimately provide a greater insight into how these protein interactions affect $\mathrm{BACE} 1$ and their role in the generation of $\beta$-amyloid.

We gratefully acknowledge the MRC (UK) for a PhD studentship, the Alzheimer's Society (UK) for support and the Biomics Unit at sgul for proteomic facilities.

\section{CONFLICTS OF INTEREST}

The authors declare no conflicts of interest regarding the publication of this paper.

\section{REFERENCES}

1. Glenner, G.G. and Wong, C.W. (1984) Alzheimer's Disease: Initial Report of the Purification and Characterization of a Novel Cerebrovascular Amyloid Protein. Biochemical and Biophysical Research Communications, 120, 885-890. https://doi.org/10.1016/S0006-291X(84)80190-4 
2. Lee, V.M., Balin, B.J., Otvos, L. and Trojanowski, J.Q. (1991) A68. A Major Subunit of Paired Helical Filaments and Derivatized Forms of Normal Tau. Science, 251, 675-678. https://doi.org/10.1126/science.1899488

3. Pike, C.J., Walencewicz, A.J., Glabe, C.G. and Cotman, C.W. (1991) Neurodegeneration Induced by Beta-Amyloid Peptides in Vitro; The Role of Peptide Assembly State. Journal of Neuroscience, 13, 1676-1687. https://doi.org/10.1523/JNEUROSCI.13-04-01676.1993

4. Yankner, B.A., Duffy, L.K., Kirschjner, D.A. and Yankner, B.A. (1990) Neurotrophic and Neurotoxic Effects of Amyloid Beta Protein: Reversal by Tachykinin Neuropeptides. Science, 250, 279-282. https://doi.org/10.1126/science.2218531

5. Lopez-Perez, E., Zhang, Y., Frank, S.J., Creemers, J., Seidah, N. and Checler, F. (2001) Constitutive Alpha-Secretase Cleavage of the Beta-Amyloid Precursor Protein in the Furin-Deficient LoVo Cell Line: Involvement of the Pro-Hormone Convertase 7 and the Disintegrin Metalloprotease ADAM10. Journal of Neurochemistry, 76, 1532-1539. https://doi.org/10.1046/j.1471-4159.2001.00180.x

6. Hussain, I., Powell, D., Howlett, D.R., Tew, D.G., Meek, T.D., Chapman, C., Gloger, I.S., Murphy, K.E., Southan, C.D., Ryan, D.M., Smith, T.S., Simmons, D.L., Walsh, F.S., Dingwall, C. and Christie, G. (1999) Identification of a Novel Aspartic Protease (Asp 2) as Beta-Secretase. Molecular and Cellular Neurosciences, 14, 419-427. https://doi.org/10.1006/mcne.1999.0811

7. Sinha, S., Anderson, J.P., Barbour, R., Basi, G.S., Caccavello, R., Davis, D., Doan, M., Dovey, H.F., Frigon, N., Hong, J., Jacobson-Croak, K., Jewett, N., Keim, P., Knops, J., Lieberburg, I., Power, M., Tan, H., Tatsuno, G., Tung, J., Schenk, D., Seubert, P., Suomensaari, S.M., Wang, S., Walker, D., Zhao, J., McConlogue, L. and John, V. (1999) Purification and Cloning of Amyloid Precursor Protein Beta-Secretase. Nature, 402, 537-540. https://doi.org/10.1038/990114

8. Lin, X., Koeksch, G., Wu, S., Downs, D., Dashti, A. and Tang, J. (2000) Human Aspartic Protease Memapsin 2 Cleaves the Beta-Secretase Site of Beta-Amyloid Precursor Protein. Proceedings of the National Academy of Sciences of the United States of America, 97, 1456-1460. https://doi.org/10.1073/pnas.97.4.1456

9. Solans, A., Estivill, X. and de La Luna, S. (2000) A New Aspartyl Protease on 21q22.3, BACE2, Is Highly Similar to Alzheimer's Amyloid Precursor Protein Beta-Secretase. Cytogenetics and Cell Genetics, 89, 177-184. https://doi.org/10.1159/000015608

10. Acquati, F., Accarino, M., Nucci, C., Fumagalli, P., Jovine, L., Ottolenghi, S. and Taramelli, R. (2000) The Gene Encoding DRAP (BACE2), a Glycosylated Transmembrane Protein of the Aspartic Protease Family, Maps to the down Critical Region. FEBS Letters, 468, 59-64. https://doi.org/10.1016/S0014-5793(00)01192-3

11. Farzan, M., Schnitzler, C.E., Vasilieva, N., Leung, D. and Choe, H. (2000) BACE2, a Beta-Secretase Homolog, Cleaves at the Beta Site and within the Amyloid-Beta Region of the Amyloid-Beta Precursor Protein. Proceedings of the National Academy of Sciences of the United States of America, 97, 9712-9717. https://doi.org/10.1073/pnas.160115697

12. Parsons, R.B. and Austen, B.M. (2008) Post-Translational Modifications and Cellular Targeting of Beta-Secretase. In: Araki, W., Ed., Recent Advances in the Biology of Secretases, Key Proteases in Alzheimer's Disease, Research Signpost, 1-38.

13. Haniu, M., Denis, P., Young, Y., Mendiaz, E.A., Fuller, J., Hui, J.O., Bennett, B.D., Kahn, S., Ross, S., Burgess, T., Katta, V., Rogers, G., Vassar, R. and Citron, M. (2000) Characterization of Alzheimer's Beta-Secretase Protein BACE. A Pepsin Family Member with Unusual Properties. The Journal of Biological Chemistry, 275, 21099-21106. https://doi.org/10.1074/jbc.M002095200

14. Charlwood, J., Dingwall, C., Matico, R., Hussain, I., Johanson, K., Moore, S., Powell, D.J., Skehel, J.M., Ratcliffe, S., Clarke, B., Trill, J., Sweitzer, S. and Camilleri, F. (2001) Characterization of the Glycosylation Profiles of Alzheimer's Beta-Secretase Protein Asp-2 Expressed in a Variety of Cell Lines. The Journal of Biological Chemistry, 
276, 16739-16748. https://doi.org/10.1074/jbc.M009361200

15. Walter, J., Fluhrer, R., Hartung, B., Willem, M., Kaether, C., Capell, A., Lammich, S., Multhaup, G. and Haass, C. (2001) Phosphorylation Regulates Intracellular Trafficking of $\beta$-Secretase. The Journal of Biological Chemistry, 276, 14634-14641. https://doi.org/10.1074/jbc.M011116200

16. Citron, M., Eckman, C.B., Diehl, T.S., Corcoran, C., Ostaszewski, B.L., Xia, W., Levesque, G., St George Hyslop, P., Younkin, S.G. and Selkoe, D.J. (1998) Additive Effects of PS1 and APP Mutations on Secretion of the 42-Residue Amyloid Beta-Protein. Neurobiology of Disease, 5, 107-116. https://doi.org/10.1006/nbdi.1998.0183

17. Vassar, R., Bennett, B.D., Babu-Khan, S., Kahn, D., Mendiaz, E.A., Denis, P., Teplow, D.B., Ross, S., Amarante, P., Loeloff, R., Luo, Y., Fisher, S., Fuller, J., Edenson, S., Lile, J., Jarosinski, M.A., Biere, A.L., Curran, E., Burgess, T., Louis, J.C., Collins, D., Treanor, J., Rogers, G. and Citron, M. (1999) Beta-Secretase Cleavage of Alzheimer's Amyloid Precursor Protein by the Transmembrane Aspartic Protease BACE. Science, 286, 735-741. https://doi.org/10.1126/science.286.5440.735

18. Austen, B., Christadoulou, G. and Terry, J.E. (2002) The Relation of Cholesterol Levels, Statins and Alzheimer's Disease in the Human Population. The Journal of Nutrition, Health and Aging, 6, 377-382.

19. Fraering, P.C., Ye, W., Strub, J.M., Dolios, G., LaVoie, M.J., Ostaszewski, B.L., van Dorsselaer, A., Wang, R., Selkoe, D.J. and Wolfe, M.S. (2004) Purification and Characterization of the Human Gamma-Secretase Complex. Biochemistry, 43, 9774-9789. https://doi.org/10.1021/bi0494976

20. Bruinzeel, W., Yon, J., Giovannelli, S. and Masure, S. (2002) Recombinant Insect Cell Expression and Purification of Human Beta-Secretase (BACE-1) for X-Ray Crystallography. Protein Expression and Purification, 26, 139-148. https://doi.org/10.1016/S1046-5928(02)00516-8

21. Mallender, W.D., Yager, D., Onstead, L., Nichols, M.R., Eckman, C., Sambamurti, K., Kopcho, L.M., Marcinkeviciene, J., Copeland, R.A. and Rosenberry, T.L. (2001) Characterization of Recombinant, Soluble Beta-Secretase from an Insect Cell Expression System. Molecular Pharmacology, 59, 619-626.

https://doi.org/10.1124/mol.59.3.619

22. Sardana, V., Xu, B., Zugay-Murphy, J., Chen, Z., Sardana, M., Darke, P.L., Munshi, S. and Kuo, L.C. (2004) 18. A General Procedure for the Purification of Human Beta-Secretase Expressed in Escherichia coli. Protein EXpression and Purification, 34, 190-196. https://doi.org/10.1016/j.pep.2003.12.014

23. Tomasselli, A.G., Paddock, D.J., Emmons, T.L., Mildner, A.M., Leone, J.W., Lull, J.M., Cialdella, J.I., Prince, D.B., Fischer, H.D., Heinrikson, R.L. and Benson, T.E. (2008) High Yield Expression of Human BACE Constructs in Eschericia coli for Refolding, Purification, and High Resolution Diffracting Crystal Forms. Protein \& Peptide Letters, 15,131-143. https://doi.org/10.2174/092986608783489553

24. Pappin, D.J., Hojrup, P. and Bleasby, A.J. (1993) Rapid Identification of Proteins by Peptide-Mass Fingerprinting. Current Biology, 3, 327s-332s. https://doi.org/10.1016/0960-9822(93)90195-T

25. Sharoar, M.G. and Yan, R. (2017) Effects of Altered RTN3 Expression on BACE1 Activity and Alzheimer's Neuritic Plaques. Reviews in the Neurosciences, 28,145-154. https://doi.org/10.1515/revneuro-2016-0054

26. Murayama, K.S., Kametani, F., Saito, S., Kume, H., Akiyama, H. and Araki, W. (2006) Reticulons RTN3 and RTN4-B/C Interact with BACE1 and Inhibit Its Ability to Produce Amyloid Beta-Protein. European Journal of Neuroscience, 24,1237-1244. https://doi.org/10.1111/j.1460-9568.2006.05005.X

27. Oertle, T., van der Haar, M.E., Bandtlow, C.E., Robeva, A., Burfeind, P., Buss, A., Huber, A.B., Simonen, M., Schnell, L., Brösamle, C., Kaupmann, K., Vallon, R. and Schwab, M.E. (2003) Nogo-A Inhibits Neurite Outgrowth and Cell Spreading with Three Discrete Regions. Journal of Neuroscience, 23, 5393-5406. https://doi.org/10.1523/JNEUROSCI.23-13-05393.2003

28. Yang, Y.S. and Strittmatter, S.M. (2007) The Reticulons: A Family of Proteins with Diverse Functions. Genome 
Biology, 8, 234. https://doi.org/10.1186/gb-2007-8-12-234

29. He, W., Hu, X., Shi, X.Z., Lu, Y., Fisher, C. and Yan, R. (2006) Mapping of Interaction Domains Mediating Binding between BACE1 and RTN/Nogo Proteins. Journal of Molecular Biology, 363, 625-636. https://doi.org/10.1016/j.jmb.2006.07.094

30. Ghosh, A.K., Venkateswara Rao, K., Yadav, N.D., Anderson, D.D., Gavande, N., Huang, X., Terzyan, S. and Tang, J. (2012) Structure-Based Design of Highly Selective $\beta$-Secretase Inhibitors: Synthesis, Biological Evaluation, and Protein-Ligand X-Ray Crystal Structure. Journal of Medicinal Chemistry, 55, 9195-9207. https://doi.org/10.1021/jm3008823 